\title{
Commitment to Online Community and Continuance Intention: Issue Involvement, Interactivity, and Social Interaction
}

\author{
SONY KUSUMASONDJAJA \\ Departement of Management, Faculty of Economics and Business, Universitas Airlangga, Surabaya 60286, Indonesia \\ Email correspondence: s.kusumasondjaja@feb.unair.ac.id
}

\begin{abstract}
The purposes of this study is to investigate how issue involvement, online interactivity, and social interaction influence consumer commitment to online travel community and intention to continue participating in the community. An online traveling forum was examined as the issues being observed in this study are highly relevant with the forum. Based on 135 valid responses from active members of the forum obtained through distributing online questionnaire in the forum, structural equation modelling was employed to examine the research model. The results show that issue involvement and social interaction affect commitment to the community; while surprisingly social interaction does not have significant influence on the commitment. Moreover, commitment to the community leads consumers to continue their participation in the community. Managerial contributions and limitations of the study are discussed.
\end{abstract}

Key words: Online Community, Issue Involvement, Interactivity, Social Interaction, Commitment

\section{Komitmen terhadap Komunitas Online dan Continuance Intention: Issue Involment, Interactivity, dan Social Interaction}

\begin{abstract}
Abstrak
Penelitian ini bertujuan untuk menguji bagaimana issue involvement, online interactivity, dan social interaction mempengaruhi komitmen konsumen pada komunitas perjalanan online dan niat untuk terus berpartisipasi dalam komunitas tersebut. Sebuah forum travel online di Indonesia diteliti karena dianggap relevan dengan masalah yang diteliti. Berdasarkan 135 respon valid dari anggota aktif forum online tersebut yang diperoleh melalui survey online, model persamaan structural digunakan untuk menguji model penelitian. Hasil pengujian statistic menunjukkan bahwa issue involvement dan social interaction mempengaruhi komunitmen pada komunitas dan niat untuk terus berpartisipasi dalam komunitas, namun social interaction tidak memiliki pengaruh signifikan pada komitmen. Komitmen pada komunitas membuat konsumen untuk melanjutkan partisipasi pada komunitas tersebut. Kontribusi manajerial dan kelemahan penelitian didiskusikan lebih lanjut.
\end{abstract}

Kata kunci: Komunitas Online, Issue Involvement, Interactivity, Social Interaction, Komitmen. 


\section{INTRODUCTION}

In the last few years, the adoption and diffusion of Internet technology have altered the landscape of tourism industry worldwide (Buhalis and Law 2008). From tourism organisations' standpoint, the Internet have changed radically the efficiency and effectiveness of tourism management, as well as how travelers interact with the tourism organization (Shuckert et al. 2015). From consumer's perspective, this new technological platform has affected how travelers around the world use technology for planning and experiencing their trip (Sparks et al. 2013). This Internet revolution stimulates the emergence of many online travel communities, especially those organized by travelers themselves. Some typical examples in Indonesia are JalanSutra; where members can share their travel and culinary experiences or ask questions about travel tips and tricks; or Backpacker Indonesia; where young travelers who love to travel light on budget tell their travel stories. Members are also enabled to join the discussion forums for supplementary information exchange. Some international examples include TravBuddy or Travellers Point.

By joining these communities, travelers can make better travel plan by obtaining support from fellow travelers who have "been there, done that." Insightful information about hotels, restaurants, trips, or cruises is also accessible by them from the online sources. Interestingly, online communities have revolutionized how travellers communicate with each other (Lee and Hyun 2015). As a result, those communities have changed the way of online interaction is conducted whereby most travelers can have two-way interaction with fellow travellers without having time or geographical limitations for obtaining travel-related information, maintaining social relationships, finding vacation partners, getting updated travel tips and suggestions, or exchanging interesting travel stories (Lee et al. 2012; Kang and Schuetts 2013; Kunz and Seshadri 2015).

Online community has been perceived to be an effective tool for managing relationships with customers (Kang et al. 2014); including in travelling context. It is believed that online travel community will significantly increasingly important for tourism organizations in the following years as the Internet currently becomes more prevalent (Hays et al. 2013; Standing et al. 2014). In addition, as a customer relationship management (CRM) tool online travel community will support tourism businesses to sustain relationships with their customers, intimately engage with customers through two-way interactions with other members based on their mutual interests; and maintain customers by enhancing relationships with fellow travellers (Castronovo and Huang 2012; Khodakarami and Chan 2014; Jung et al. 2013).

Although the thought of community is an old conception that defines the nature of human civilization, the emergence of computer-mediated communities has generated a significant interest among current academics (i.e. Elliot et al. 2013; Kunz and Seshadri 2015; Nusair et al. 2013; Tsai and Pai 2013) as well as business practitioners (Bayus 2013; Boudreau and Lakhani 2013). However, there are still existing challenges for travel organizations to be able to effectively adopt this model for their business purposes.

Welbourne et al. (2013) suggested that the success of a virtual community essentially relies on how well the organizations understand their members for sustaining the existence of their participation. Young (2013) stated that successful online communities focus on their members' needs instead of the sponsors or administors' interests. Attracting users is less important than sustaining active members participating in the community (Kuo and Feng 2013). Furthermore, Liao et al. (2013) mentioned in their research that members' willingness to share their knowledge with other members is crucial in sustaining the existence of virtual community. The main problem is the fact that it is difficult to encourage members to actively participate and share their knowledge in the community when the members feel disconnected with, or less attached emotionally to, the community (Chiu et al. 2011). Wang and Chen (2012) suggested that when community members tend to participate actively in the community when they feel involved in the issues concerned by the community. When the issues discussed in the community are considered as relevant or important or interesting by members, they are more likely to involve in the discussion. Moreover, online community facilitates members 
to develop social interaction that helps knowledge sharing and information exchanging process to occur (Zhao et al. 2012). Shih and Huang (2014) also found that web interactivity helps members to enjoy their interaction in the online community.When the system enables online performance as expected by the members, they are more likely to be committed and keep contributing to the community.

Thus, an understanding of the underlying factors that drive members to keep participating to the community is paramount for tourism marketing organizations who incorporate online community into their business practices. The aim of this study is to answer these following questions: (1) whether or not issue involvement, social interaction, and online interactivity affect members' commitment to the community, (2) whether or not members' commitment to the community influences their intention to continue their participation in the community?

\section{LITERATUR REVIEW}

\section{Issue Involvement}

Involvement is considered an individual difference variable. Depending on level of involvement, consumers will greatly vary in their responses to marketing stimuli. In their classical theory, Lauren and Kapferer (1985) conceptualized involvement into five different dimensions; namely: (a) the importance of a product for an individual, (b) enjoyment or hedonic values resulted from a product, (c) symbolic value related with particular products, (d) possible risk resulted from potential mistakes in product purchase, and (e) risk consequences resulted from the purchase mistake. Issue involvement itself relates with individual relevance, interests, and value related with particular objects (Wang et al, 2012). Houston and Rothschild (1978) classified involvement into three types; namely: situational involvement, enduring involvement, and response involvement. According to Wang et al (2012), issue involvement in a virtual community is a form of enduring involvement. Enduring involvement occurs when there is a match between personal needs, objectives, and values and attributes of an activity (Kyle et al. 2007). The foundation of enduring involvement exists from the intention to satisfy specific needs and achieve personal objectives.

Wang et al. (2003) explains that level of member involvement with goal-object affects level of member motivation to participate in an online community. Level of member involvement can be very aggressive or very complaisant depending on individual's willingness (Chang and Chuang, 2011). Wang et al (2012) explain that issue involvement can be classified as enduring involvement which focusing on individual's interests in continual basis, instead of temporal interests. Michaelidou \& Dibb (2008) also mentioned that enduring involvement represents long-term individual attachment to particular product or object. When an individual is involved with the issues being concerned by members of an online community, the individual is more likely to commit to the community. On the other hand, when the issues discussed in the community is considered irrelevant by the members, they are less likely to commit to the community. Based on the explanation above, this following hypothesis is proposed:

H1: The higher the level of issue involvement, the greater the level of member commitment to the online community.

\section{Social Interaction}

An online community consists of individuals interacting intensively on an Internet-based media platform (Chang and Chuang, 2011). In such community, meaningful learning and information attainment are achieved by social interaction when members have willingness to exchange information, provoke inspiring questions and suggest fruitful opinions to grow their individual intellectuality (eg, Cheung et al. 2015). Interaction among peers is important in enhancing learning among community members (Oh et al. 2014). Reflective comments from other members are also valuble for enabling learners to make their own connections with each other. Social learning theory provides a theoretical framework of how social interaction among members is related to meaningful learning occurred to the individual members. It is suggested that good interaction among members in a social environment is vital for the process of knowledge acquisition and learning to occur through active participation in that community (Cheung et al. 2015). Another study by Zheng and Warschauer (2015) confirms that when students have 
JURNAL BISNIS \& MANAJEMEN

ISSN 1412 - 3681

strong interaction in their social environment they tend to gain good academic performance.

In an online community context, social interaction is defined as the extent in which members of online community have high the level of social interaction, communication, and familiarity with other members (Wang et al. 2012). Social interaction approach in Shen et al (2010) observed interpersonal interaction experience as the main service provided by online community. Referring to Hummel and Lechner (2002), communication services such as online chat or forum features support most online communication activities and facilitate social interaction in an online community. Successful interaction in an online communite can be seen from the any available effort to enable the occurance of social interaction among members (Matzat, 2010; Shen et al, 2010).

Wang and Fesenmaier (2003) explain that one of the reasons consumers join an online community is to satisfy their social needs; the needs to interact socially with other people who share similar interests. Adopting from Wang et al (2012), when the higher the level of social interaction, the more familiar members with community norms and values. When members are familiar with what is expected from them, they enjoy their online experience with the community, feel the dynamics in the community, and are likely to commit to stay in the community (Doney et al 2007). Preece et al (2004) suggested that members tend to leave a virtual community which has limited interaction. Based on the explanation above, this following hypothesis is proposed.

$\mathrm{H} 2$ : The higher the level of social interaction as perceived by members, the greater the member commitment to the community

\section{System Interactivity}

Web interactivity is defined as the extent to which users can participate in modifying the form and content of the mediated environment in real time (Wu 2006). The construct can be categorized into two different approaches; namely structuralist or mechanistic approach and experiential approach. The structuralist or mechanistic approach views interactivity as the response to the structural properties of the online medium or website, "the hardwired opportunity of interactivity provided during an interaction" (Liu and Shrum, 2002). Recent studies defined perceived interactivity as a psychological situation experienced by a site user when the user interacts with the website (McMillan and Hwang, 2002; Wu 2006).

High quality websites can provide convenience and virtual enjoyment for their users, so that the users can well understand the function of the forum, the way to use the features, and are able to ensure the information exchange occurs efficiently (Lin, 2007). More productive ways to interactivity should be developed so that the online community can really stand out as an interactive communication media (Wu, 2006). The reason why a system is created can be acknowledged by observing what the system can perform and how the system function to achieve its objectives. In another word, if the system is made for facilitating interactions among members in an online community, the system should be developed by taking consideration of interactivity principles in order to support members to have social interaction among them.

Buchanan-Oliver and Chan (2004) confirmed that interactivity is considered having positive effect on online consumer experiences. Online system that is not well created can frustrate users and discourage them from staying at the system (Kamis et al, 2008). According to Wang et al (2013), a well-designed online community site will attract members more intensively and keep them staying longer at the community. In an interactive online forum, members enjoy entertaining, exciting, and impressive online that satisfies their expectation which eventually encourage them to commit to the community to sustain their involvement in the forum (Buchanan-Oliver and Chan 2004). Wang et al (2012) explains that online community system that enables members to have high level of interactivity will be able to generate members' commitment to stay at and keep contributing to the community. Based on the conceptual explanation above, this following hypothesis is proposed:

H3: The higher the level of web interactivity as perceived by members, the greater the member commitment to the community

\section{Commitment}

Meyer et al (2002) categorized three components 
of commitment types; namely affective, normative, and continuance commitment. Referring to Demirtas and Akdogan (2015), affective commitment is the extent in which an individual enjoy, emotionally involve, and identify themselves as member in a community. Kimura (2013) added that members with affective commitment commonly initiate some efforts to stay in the community. Meanwhile, normative commitment occurs when an individual is willing to participate in a community because of several reasons; such as expecting some benefit by joining it; that make them motivated to stick with the community (Fullerton 2014). Finally, Guay et al. (2016) suggested that continuance commitment is an emotional attachment to a community based on cost benefit analysis consideration of leaving or staying. In online community context, continuance intention is actually generated from members' satisfaction and loyalty to the community. The construct of continuance intention is conceptually similar to purchase intention as both states are influenced by previous condition experienced by individuals (Guay et al. 2016). Continuance intention can be clustered into two different types: first, the intention to keep consuming the content provided by the online community, and second, the intention to continue contributing information to the other members in the community (Zhao et al. 2012).
When an online community wants its existence to sustan in a long term, it is important for the community to encourage its members to actively participate by asking questions, providing information, posting comments, or any other forms of contributions (Jin et al., 2009). Zhou et al. (2012) and Hsu et al (2010) found that members who have committed to the community are most likely to feel obliged to participate and contribute to the community in order to sustain its existence. Cheung and Lee (2009) suggested that the greater the commitment of members to the community, the greater their intention to continue participating in the community. Based on the explanation above, this following hypothesis is proposed:

$\mathrm{H} 4$ : The greater the commitment of members to the community, the greater their intention to continue participating in the community

\section{RESEARCH METHOD}

Measurement scales were adapted from established scales; issue involvement from de Graaf et al (2015), social interaction from Blazevic et al (2014), web interactivity from van Noort et al (2012), commitment from Bilgihan et al (2013), and continuance intention from Sun et al. (2014). Table 1 shows the scale items used in this study.

Table 1. Questionnaire Table

\begin{tabular}{|c|c|c|}
\hline Variables & Definition & Indicators \\
\hline \multirow{6}{*}{$\begin{array}{l}\text { Issue } \\
\text { involvement }\end{array}$} & \multirow{6}{*}{$\begin{array}{l}\text { Individual's perception regarding the relevance of } \\
\text { issues discussed in an online community } \\
\text { (de Graaf et al 2015) }\end{array}$} & For me, traveling issue is important \\
\hline & & For me, traveling issue is of great concern \\
\hline & & For me, traveling issue means a lot \\
\hline & & For me, traveling issue matters a lot \\
\hline & & For me, traveling issue is significant \\
\hline & & Travelling issue is relevant to my interest \\
\hline \multirow{5}{*}{$\begin{array}{l}\text { Social } \\
\text { interaction }\end{array}$} & \multirow{5}{*}{$\begin{array}{l}\text { Perceived of interaction and communication } \\
\text { intensity among members in an online } \\
\text { information (Blazevic et al. 2014) }\end{array}$} & I use this community to stay in touch with my friends \\
\hline & & I use this community to express my ideas and opinion to other members \\
\hline & & I spend a lot of time to interact with other members of this community \\
\hline & & I personally know other members well \\
\hline & & I maintain close relationship with other members of this community \\
\hline \multirow{4}{*}{$\begin{array}{l}\text { Web } \\
\text { interactivity }\end{array}$} & \multirow{4}{*}{$\begin{array}{l}\text { Evaluation about system capability in facilitating } \\
\text { interaction activity in online community } \\
\text { (van Noort et al 2012) }\end{array}$} & Interacting with other members in this community website is easy \\
\hline & & $\begin{array}{l}\text { This community website supports me in interacting with other members of the } \\
\text { community }\end{array}$ \\
\hline & & This community website provides information that I can easily access \\
\hline & & $\begin{array}{l}\text { Overall, for me having online interaction with other members using this community } \\
\text { website is easy }\end{array}$ \\
\hline
\end{tabular}


Continue of Table 1. Questionnaire Table

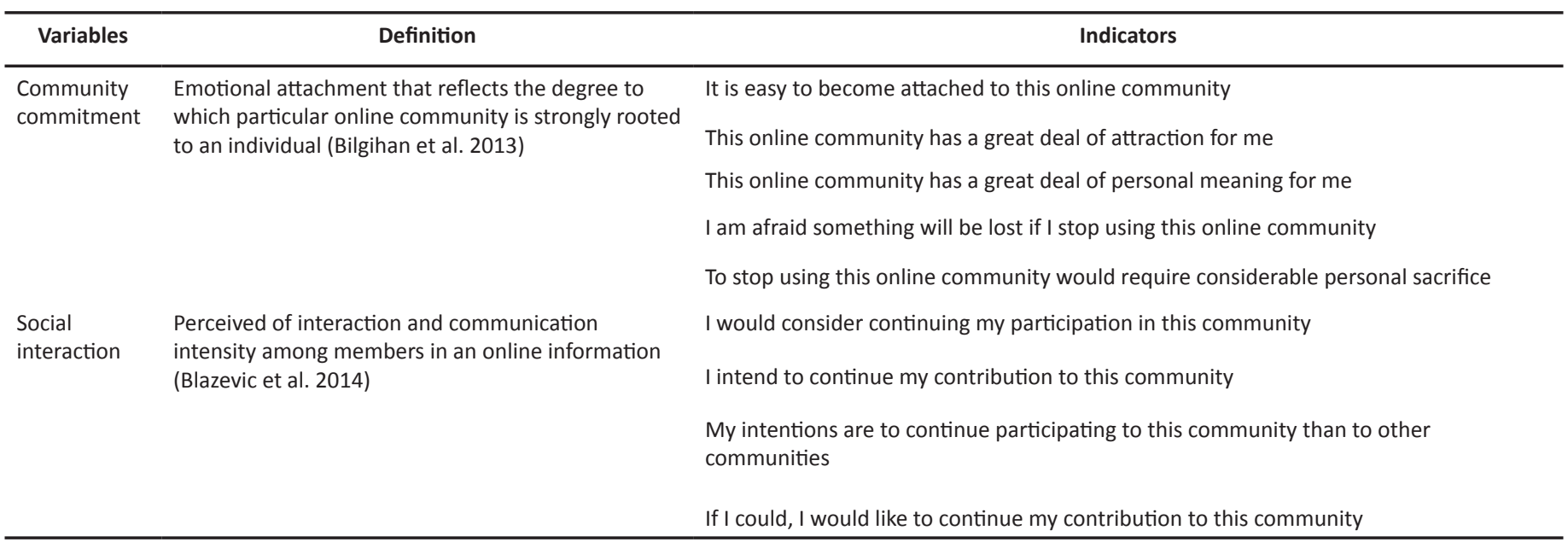

An online survey was conducted for data collection by distributing questionnaire on three online travel communities in Indonesia from October to December 2015. The three communities were chosen due to its popularity (number of members) and high level of online activity (number of posts or threads). Involving real members instead of using student samples was aimed at enhancing level of representativeness of population being studied (Voracek 2001) since using student samples may not be proper in this context (Yavas 1994) and may lead to a biased result (Peterson 2001). This study involved 135 members participating as respondents. Among the respondents, most of the respondents were male (64\%), had at least bachelor degree (76\%), most worked as employee (48\%), and mostly considered themselves as experienced member in the community they are following.

Data for this study was obtained from an Indonesian virtual travel community having more than 150,000 members. Access to the survey provided to the target respondents was facilitated by providing a link which led the respondent to the online questionnaire. The travel community then sent a general post to all members informing the survey activity. The survey was conducted more than 2-week period on October 2015 resulting a total of 135 usable responses. As suggested by Autio et al. (2013), an important limitation in this study is self-selection process conducted by the respondents. In this typical study in virtual community context, self-selection problem is difficult to avoid since online community members cannot be demanded to fill out a survey questionnaire.

\section{RESULTS AND DISCUSSION}

\section{Findings}

To assess the quality of measurement used in this study, confirmatory factor analysis and reliability tests were conducted. The measurement model was examined using criteria of overall fit with the data, convergent validity, and reliability. The results are reported in Table 2 and Table 3. Results of measurement model evaluation suggested that internal consistency and convergent validity is good; as suggested in Table 2.

Table 2. Factor Loadings and Reliability Tests for the Measurement Model

\begin{tabular}{lcc}
\hline Construct & Corrected Item-to-Total Correlation & Cronbach's Alpha \\
\hline Issue Involvement & 0,908 \\
Issue1 & 0,605 & \\
Issue2 & 0,612 & \\
Issue3 & 0,653 & \\
Issue4 & 0,671 & \\
Issue5 & 0,626 & \\
Issue 6 & 0,701 & \\
\hline Social Interaction & & \\
Interaction1 & 0,604 \\
Interaction2 & 0,628 & \\
Interaction3 & 0,577 & \\
Interaction4 & 0,469 & \\
Interaction5 & 0,617 & \\
\hline Web Interactivity & & \\
Interactivity1 & 0,645 & \\
Interactivity2 & 0,750 & \\
Interactivity3 & 0,692 & \\
Interactivity4 & 0,560 & \\
\hline & & \\
\hline
\end{tabular}


Continue of Table 2. Factor Loadings and Reliability Tests for the Measurement Model

\begin{tabular}{lcc}
\hline Construct & Corrected Item-to-Total Correlation & Cronbach's Alpha \\
\hline Commitment to Community & & $\mathbf{0 . 9 3 4}$ \\
Commitment1 & 0,811 & \\
Commitment2 & 0,840 & \\
Commitment3 & 0,837 & \\
Commitment4 & 0,725 & $\mathbf{0 , 9 3 8}$ \\
Commitment5 & 0,835 & \\
\hline Issue Involvement & & \\
Intention1 & 0,778 & \\
Intention2 & 0,789 & \\
Intention3 & 0,752 & \\
Intention4 & 0,840 & \\
\hline
\end{tabular}

Table 3. Goodness-of-Fit Summary for the Measurement Model

\begin{tabular}{ccccccc}
\hline Model & df & $\mathbf{P}$ & GFI & CFI & TLI & RMSEA \\
\hline Measurement & 189 & 0.00 & 0.819 & 0.943 & 0.930 & 0.079 \\
\hline
\end{tabular}

To test the structural model in this study, Amos 4.0 (Byrne 2013) was used using path analysis. The full structural model was evaluated first and a revised model was then obtained by retaining only those paths whose coefficients were significant $(p \leq .00)$. Table 3 reported the goodness-of-fit statistics of the modified model, meanwhile Table 4 confirmed the results for the path coefficients of the modified model. The overall fit of the model is significant $(\chi 2=347.33, p<.00)$. As the scores of GFI (.93), CFI (.96), RMSEA (0.079) and the Normed Fit Index (NFI) (.95) are all within acceptable ranges (Bentler 1990), thus it implied that the overall fit of the model to the data was achieved.

Table 4. Results for Path Coefficients \& Hypotheses Testing

\begin{tabular}{lccccc}
\hline Hypotheses & Estimate & S.E. & C.R. & Probability & Results \\
\hline $\begin{array}{l}\text { Involvement -> } \\
\text { Commitment }\end{array}$ & 0.513 & 0.174 & 2.949 & 0.003 & Supported \\
$\begin{array}{l}\text { Interaction -> } \\
\text { Commitment }\end{array}$ & 0.228 & 0.054 & 4.214 & 0.083 & Not supported \\
$\begin{array}{l}\text { Interactivity -> } \\
\text { Commitment }\end{array}$ & 0.651 & 0.173 & 3.771 & 0.000 & Supported \\
$\begin{array}{l}\text { Commitment -> } \\
\text { Intention }\end{array}$ & 0.888 & 0.076 & 11.661 & 0.000 & Supported \\
\hline
\end{tabular}

To test the hypotheses, the path coefficients and their significance values were used. Results for path coefficient scores is shown in Table 4, whereas Figure 1 shows the result of hypothesized structural model.

Figure 1. Results for Hypothesized Model

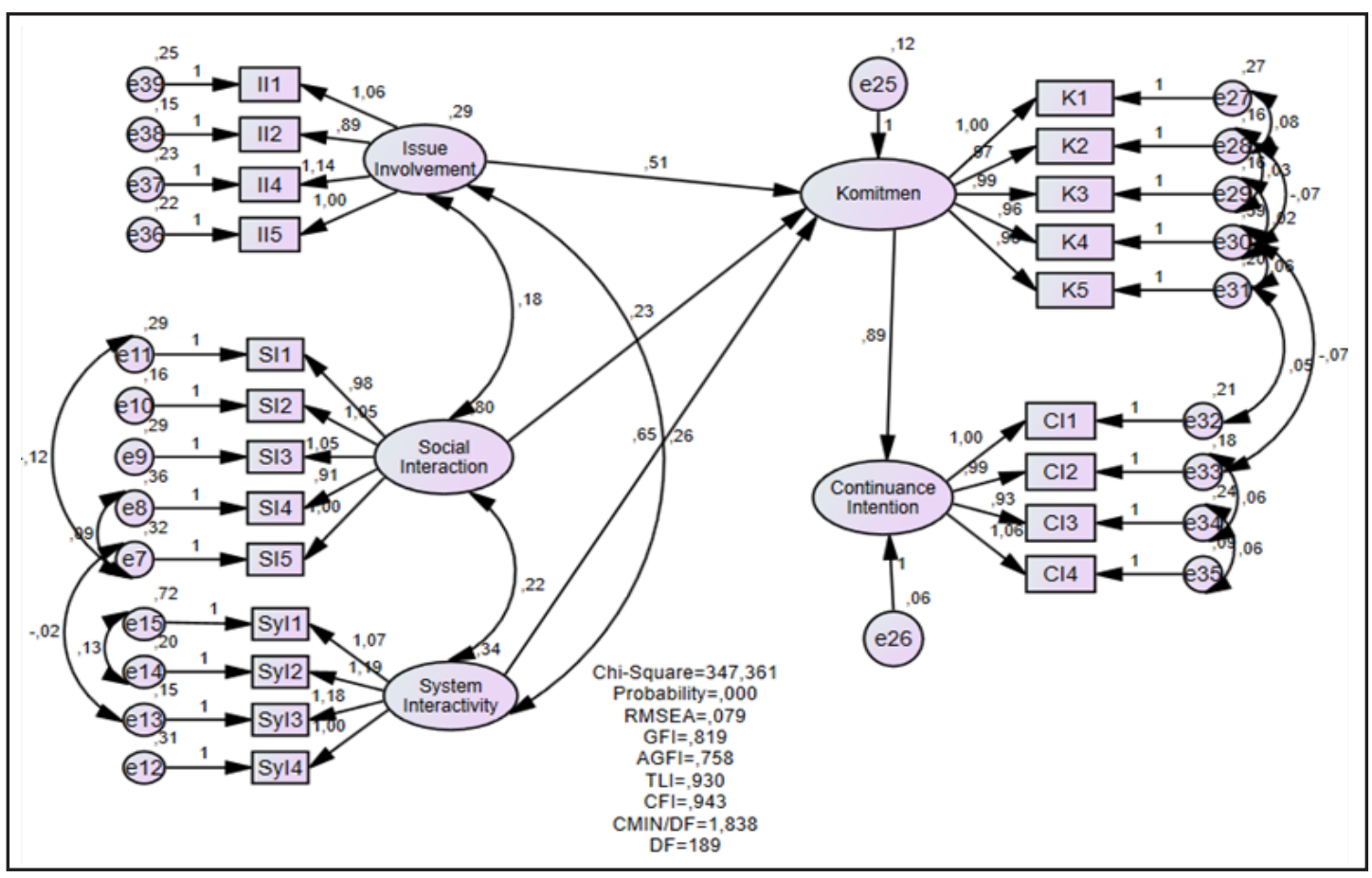


Statistical results revealed that $\mathrm{H} 1$ is supported; meaning that issue involvement has positive significant effect on commitment. Based on statistical test, it was found that significance value of the effect of issue involvement on community commitment was 0,003 with path estimate 0.513 . It means that the greater the involvement an individual has on the issue discussed in an online community, the greater the likelihood that the individual commits to the community. It is also found that social interaction doesn't have significant influences on members' community commitment; therefore $\mathrm{H} 2$ was not supported. Based on statistical test, it was found that significance value of the effect of issue involvement on community commitment was 0,083 with path estimate 0.228 . It means that there is no significant influence of the level of social interaction an individual has with an online community with the individual's commitment to the community.

Web interactivity is also found to have significant influence on community commitment; therefore $\mathrm{H} 3$ was supported. Based on statistical test, it was found that significance value of the effect of web interactivity on community commitment was 0,000 with path estimate 0.651 . It means that the greater the level of web interactivity in an online community, the greater the likelihood that an individual member commits to the community. Furthermore, it is confirmed that community commitment positively influences intention to continue participating in the community. Therefore, H4 was supported. Based on statistical test, it was found that significance value of the effect of issue involvement on community commitment was 0,000 with path estimate 0.888 . It means that the greater the likelihood that the individual commits to the community, the greater the individual's intention to continue participating to the community.

\section{Discussion}

Findings of this study suggested that when members are involved on the issues discussed in the community, they are most likely to commit to the community; supporting results from previous studies (Wang et al., 2012). Issues being discussed are the focal interest point that attract individuals to visit and join an online community. Beatty et al. (1988) pointed out that commitment is the direct effect of involvement. Travelers join some communitites discussing about travelling because they are involved in traveling matters and iinterested in obtaining new information about traveling. If the community talks about some topics that are out of their interests, it is least likely that they will stay in the community.

Another finding of this research is that social interaction with other members in a community does not have a significant influence on members' commitment. Contradicts with Wang et al. (2012), this study suggests that the opportunity to be able to have an interaction with other members does not affect members' commitment to the community. In an online community with thousands of members like the ones observed in this study, it is difficult to have "real" interaction due to several problems: first, the huge amount of members encourage most members to be passive in the forum as long as they can get valuable information from the other members - this study found that $57 \%$ of respondents posted information to the community only once indicating that there were a lot of free riders or passive members, and second, online forum with large number of members makes most of them difficult to have meaningful dyadic interactions. The huge numbers of members allow the communities to generate tens or even hundreds postings per day. This situation encourages most members (especially the passive ones) to read only the information without posting anything; since reading all of those postings takes a lot of time. Most respondents in this study usually spend less than 30 minutes for the community, and they spend most of the time reading, not creating information.

Moreover, when the web system of an online community enables members to have a good quality interactivity, it is most likely that the members stay committed to the community; supporting results from previous studies (Wang et al 2012; Tan and Wei 2006). In their study, Tan and Wei (2006) argued that unwelldesigned online system that have poor interactivity can result frustration among members which eventually drives them to leave the forum. Conversely, when members feel enjoyment in experiencing the online system, their commitment to stay in the community will be enhanced (Buchanan-Oliver and Chan 2004). Gupta and Kim (2010) stated that good online system quality as perceived by members will escalate the perceived value they obtain from the community that motivate them to commit to stay. According to Chen 
and Yen (2004), good interactivity quality of an online system involves web design, online appearance and layout, and the speed of entry loading. In addition, members who have commitment to the community will be likely to continue their participation to the community; supporting findings from Cheung and Lee (2009). Referring to Jin et al. (2009), an online community depends on active participation from its members to sustain their existence.

\section{CONCLUSION AND RECOMMENDATION}

\section{Conclusion}

The most interesting finding of this study is that online interactivity and issue involvement are the two factors driving consumers to commit to an online community, while social interaction does not have significant influence on commitment. When online forum facilitates good interaction among its members, they have the opportunity to share knowledge and exchange information about issues of common interests. According to Baron et al (2010), the implementation of relationship marketing pays attention to the importance of retaining consumers as well as gaining them. The online communities need to emphasize their concern on this issue as the sustainability of an online community heavily relies on the willingness of its members to stay in the community and keep on exchanging knowledge or sharing information. Ouwersloot and OdekerkenSchroder (2008) argue that members who keep interacting with a particular online community tend to feel connected and involved with the community; and eventually have the intention to continue their participation.

Lin (2007) suggests that high quality online community can generate online comfort for its users. It commonly has the ability to facilitate good information exchange and intense online interaction among its members. Having said that, the administrators of online community should pay attention to the facilities and appearance of the content in order to create flow condition that may lead the members to spend more time in the community (Gao and Bai 2014). Moreover, since this study observed an online travel community, the administrators need to attract members by initiating interesting posts whenever necessary. When the topics keep updated and fresh, members tend to stay following the posts and may be interested to participate in the discussion. The interactivity and topics or issues being discussed need to be managed as those two factors that were found to influence members' commitment to continue their participation to the community. Refering to the study of Wang et al (2012), well-designed virtual community sites tend to attract members' attention more often and stimulate them to spend more time in the community. When members are willing to spend more time, it can be expected that they contribute more to the community (Brodie et al 2013).

This study offers managerial contributions in the marketing area about how to manage members' commitment to online communities. Zhao et al (2012) state that commitment to communities commonly means commitment to continue participating in the information and knowledge exchanging activities. Findings of this research are expected to help online communities to sustain their existence by managing member participation in the community. Paying attention to the interactivity of the forum and the issues being discussed are some of the tactics that may be adopted following the results of this study.

Regardless the value of managerial contributions offered by this study, there are also some limitations need to address. The nature of online survey limits the ability of researchers to control the profiles and the number of respondents participating in the study. It is also difficult to approach members to increase level of responses. The situation limits the study to obtain more responses.

Further research may expand the investigation by examining some other variables related to the online community; such as online flow or trust. Investigating more variables may enhance knowledge contribution of research in this area and escalate understanding on the managerial issues of online community. Examining different types of online community is also recommended for the next study as different community may have different arrangements or features that may influence the roles of involvement, interactivity, and interaction in forming commitment. 
JURNAL BISNIS \& MANAJEMEN

ISSN 1412 - 3681

\section{REFERENCE}

Autio, E., Dahlander, L., \& Frederiksen, L. (2013). Information exposure, opportunity evaluation, and entrepreneurial action: An investigation of an online user community. Academy of Management Journal, 56(5), 1348-1371.

Baron, S., Conway, T., \& Warnaby, G. (2010). Relationship Marketing: A Consumer Experience Approach. Sage Publications.

Bayus, B. L. (2013). Crowdsourcing new product ideas over time: An analysis of the Dell IdeaStorm community. Management Science, 59(1), 226-244.

Beatty, S. E., Homer, P., \& Kahle, L. R. (1988). The involvement-commitment model: Theory and implications. Journal of Business Research, 16(2), 149-167.

Bentler, P. M. (1990). Comparative fit indexes in structural models. Psychological Bulletin, 107(2), 238-246

Bilgihan, A., Okumus, F., \& Cobanoglu, C. (2013). Generation $Y$ travelers' commitment to online social network websites. Tourism Management, 35, 13-22.

Blazevic, V., Wiertz, C., Cotte, J., de Ruyter, K., \& Keeling, D. I. (2014). GOSIP in cyberspace: Conceptualization and scale development for general online social interaction propensity. Journal of Interactive Marketing, 28(2), 87-100.

Boudreau, K. J., \& Lakhani, K. R. (2013). Using the crowd as an innovation partner. Harvard Business Review, 91(4), 60-69.

Brodie, R. J., Ilic, A., Juric, B., \& Hollebeek, L. (2013). Consumer engagement in a virtual brand community: An exploratory analysis. Journal of Business Research, 66(1), 105-114.

Buchanan-Oliver, M., \& Chan, N. (2004, July). Defining Interactivity: Building Relationships Online.
Jurnal Bisnis \& Manajemen, 2017, Vol. XVIII, No. 2, 90-103

In 20th Industrial Marketing and Purchasing Conference. Copenague.

Buhalis, D., \& Law, R. (2008). Progress in information technology and tourism management: 20 years on and 10 years after the Internet: The state of eTourism research. Tourism Management, 29(4), 609-623.

Byrne, B. M. (2013). Structural Equation Modeling with EQS: Basic Concepts, Applications, and Programming. Routledge.

Castronovo, C., \& Huang, L. (2012). Social media in an alternative marketing communication model. Journal of Marketing Development and Competitiveness, 6(1), 117.

Chang, H. H., \& Chuang, S. S. (2011). Social capital and individual motivations on knowledge sharing: Participant involvement as a moderator. Information \& Management, 48(1), 9-18.

Chen, K., \& Yen, D. C. (2004). Improving the quality of online presence through interactivity. Information \& Management, 42(1), 217-226.

Cheung, C. M., \& Lee, M. K. (2009). Understanding the sustainability of a virtual community: model development and empirical test. Journal of Information Science, 35(3), 279298.

Cheung, C. M., Liu, I. L., \& Lee, M. K. (2015). How online social interactions influence customer information contribution behavior in online social shopping communities: a social learning theory perspective. Journal of the Association for Information Science and Technology, 66(12), 2511-2521.

Chiu, C. M., Wang, E. T., Shih, F. J., \& Fan, Y. W. (2011). Understanding knowledge sharing in virtual communities: an integration of expectancy disconfirmation and justice theories. Online Information Review, 35(1), 134-153. 
de Graaf, A., van den Putte, B., \& de Bruijn, G. J. (2015). Effects of issue involvement and framing of a responsible drinking message on attitudes, intentions, and behavior. Journal of Health Communication, 20(8), 989-994.

Demirtas, O., \& Akdogan, A. A. (2015). The effect of ethical leadership behavior on ethical climate, turnover intention, and affective commitment. Journal of Business Ethics, 130(1), 59-67.

Doney, P. M., Barry, J. M., \& Abratt, R. (2007). Trust determinants and outcomes in global B2B services. European Journal of Marketing, 41(9/10), 1096-1116.

Elliot, S., Li, G., \& Choi, C. (2013). Understanding service quality in a virtual travel community environment. Journal of Business Research, 66(8), 1153-1160.

Fullerton, G. (2014). The moderating effect of normative commitment on the service quality-customer retention relationship. European Journal of Marketing, 48(3/4), 657-673.

Gao, L., \& Bai, X. (2014). Online consumer behaviour and its relationship to website atmospheric induced flow: Insights into online travel agencies in China. Journal of Retailing and Consumer Services, 21(4), 653-665.

Guay, R. P., Choi, D., Oh, I. S., Mitchell, M. S., Mount, M. K., \& Shin, K. H. (2016). Why people harm the organization and its members: Relationships among personality, organizational commitment, and workplace deviance. Human Performance, 29(1), 1-15.

Gupta, S., \& Kim, H. W. (2010). Value-driven Internet shopping: The mental accounting theory perspective. Psychology \& Marketing, 27(1), 13-35.

Hays, S., Page, S. J., \& Buhalis, D. (2013). Social media as a destination marketing tool: its use by national tourism organisations. Current Issues in Tourism, 16(3), 211-239.

Houston, M. J., \& Rothschild, M. L. (1978). Conceptual and methodological perspectives on involvement. Research Frontiers in Marketing: Dialogues and Directions, 184(187), 262-270.

Hsu, C. L., Liu, C. C., \& Lee, Y. D. (2010). Effect of commitment and trust towards microblogs on consumer behavioral intention: A relationship marketing perspective. International Journal of Electronic Business Management, 8(4), 292.

Hummel, J., \& Lechner, U. (2002). The Community Model of Content Management. In Towards the E-Society (pp. 231-246). Springer US.

Jin, X. L., Cheung, C. M., Lee, M. K., \& Chen, H. P. (2009). How to keep members using the information in a computer-supported social network. Computers in Human Behavior, 25(5), 1172-1181.

Jung, T. H., Ineson, E. M., \& Green, E. (2013). Online social networking: Relationship marketing in UK hotels. Journal of Marketing Management, 29(3-4), 393-420.

Kamis, A., Koufaris, M., \& Stern, T. (2008). Using an attribute-based decision support system for user-customized products online: an experimental investigation. MIS Quarterly, 159-177.

Kang, M., \& Schuett, M. A. (2013). Determinants of sharing travel experiences in social media. Journal of Travel \& Tourism Marketing, 30(1-2), 93-107.

Kang, J., Tang, L., \& Fiore, A. M. (2014). Enhancing consumer-brand relationships on restaurant Facebook fan pages: Maximizing consumer benefits and increasing active participation. International Journal of Hospitality Management, 36, 145-155.

Khodakarami, F., \& Chan, Y. E. (2014). Exploring the 
role of customer relationship management (CRM) systems in customer knowledge creation. Information \& Management, 51(1), 27-42.

Kimura, T. (2013). The moderating effects of political skill and leader-member exchange on the relationship between organizational politics and affective commitment. Journal of Business Ethics, 116(3), 587-599.

Kunz, W., \& Seshadri, S. (2015). From virtual travelers to real friends: Relationshipbuilding insights from an online travel community. Journal of Business Research, 68(9), 1822-1828.

Kuo, Y. F., \& Feng, L. H. (2013). Relationships among community interaction characteristics, perceived benefits, community commitment, and oppositional brand loyalty in online brand communities. International Journal of Information Management, 33(6), 948-962.

Kyle, G., Absher, J., Norman, W., Hammitt, W., \& Jodice, L. (2007). A modified involvement scale. Leisure Studies, 26(4), 399-427.

Laurent, G., \& Kapferer, J. N. (1985). Measuring consumer involvement profiles. Journal of Marketing Research, 41-53.

Lee, K. H., \& Hyun, S. S. (2015). A model of behavioral intentions to follow online travel advice based on social and emotional loneliness scales in the context of online travel communities: The moderating role of emotional expressivity. Tourism Management, 48, 426-438.

Lee, H., Reid, E., \& Kim, W. G. (2012). Understanding knowledge sharing in online travel communities: antecedents and the moderating effects of interaction modes. Journal of Hospitality \& Tourism Research, 1096348012451454.

Liao, C., To, P. L., \& Hsu, F. C. (2013). Exploring knowledge sharing in virtual communities. Online Information Review, 37(6), 891-909.

Lin, H. F. (2007). The impact of website quality dimensions on customer satisfaction in the B2C e-commerce context. Total Quality Management and Business Excellence, 18(4), 363-378.

Liu, Y., \& Shrum, L. J. (2002). What is interactivity and is it always such a good thing? Implications of definition, person, and situation for the influence of interactivity on advertising effectiveness. Journal of Advertising, 31(4), 53-64.

Matzat, U. (2010). Reducing problems of sociability in online communities: Integrating online communication with offline interaction. American Behavioral Scientist, 53(8), 1170-1193.

McMillan, S. J., \& Hwang, J. S. (2002). Measures of perceived interactivity: An exploration of the role of direction of communication, user control, and time in shaping perceptions of interactivity. Journal of Advertising, 31(3), 29-42.

Meyer, J. P., Stanley, D. J., Herscovitch, L., \& Topolnytsky, L. (2002). Affective, continuance, and normative commitment to the organization: A meta-analysis of antecedents, correlates, and consequences. Journal of Vocational Behavior, 61(1), 2052.

Michaelidou, N., \& Dibb, S. (2008). Consumer involvement: a new perspective. The Marketing Review, 8(1), 83-99.

Nusair, K. K., Bilgihan, A., \& Okumus, F. (2013). The role of online social network travel websites in creating social interaction for Gen $Y$ travelers. International Journal of Tourism Research, 15(5), 458-472.

Oh, H. J., Ozkaya, E., \& LaRose, R. (2014). How does online social networking 
enhance life satisfaction? The relationships among online supportive interaction, affect, perceived social support, sense of community, and life satisfaction. Computers in Human Behavior, 30, 69-78.

Ouwersloot, H., \& Odekerken-Schröder, G. (2008). Who's who in brand communities-and why?. European Journal of Marketing, 42(5/6), 571-585.

Peterson, R. A. (2001). On the use of college students in social science research: Insights from a second-order meta-analysis. Journal of Consumer Research, 28(3), 450-461.

Preece, J., Nonnecke, B., \& Andrews, D. (2004). The top five reasons for lurking: improving community experiences for everyone. Computers in Human Behavior, 20(2), 201223.

Schuckert, M., Liu, X., \& Law, R. (2015). Hospitality and tourism online reviews: Recent trends and future directions. Journal of Travel \& Tourism Marketing, 32(5), 608-621.

Shen, Y. C., Huang, C. Y., Chu, C. H., \& Liao, H. C. (2010). Virtual community loyalty: an interpersonal-interaction perspective. International Journal of Electronic Commerce, 15(1), 49-74.

Shih, H. P., \& Huang, E. (2014). Influences of Web interactivity and social identity and bonds on the quality of online discussion in a virtual community. Information Systems Frontiers, 16(4), 627-641.

Sparks, B. A., Perkins, H. E., \& Buckley, R. (2013). Online travel reviews as persuasive communication: The effects of content type, source, and certification logos on consumer behavior. Tourism Management, 39, 1-9.

Standing, C., Tang-Taye, J. P., \& Boyer, M. (2014). The impact of the Internet in travel and tourism: A research review 2001-2010. Journal of Travel \& Tourism Marketing,
31(1), 82-113.

Sun, Y., Liu, L., Peng, X., Dong, Y., \& Barnes, S. J. (2014). Understanding Chinese users' continuance intention toward online social networks: an integrative theoretical model. Electronic Markets, 24(1), 57-66.

Tan, G. W., \& Wei, K. K. (2006). An empirical study of Web browsing behaviour: Towards an effective Website design. Electronic Commerce Research and Applications, 5(4), 261-271.

Tsai, H. T., \& Pai, P. (2013). Explaining members' proactive participation in virtual communities. International Journal of Human-Computer Studies, 71(4), 475-491.

Van Noort, G., Voorveld, H. A., \& van Reijmersdal, E. A. (2012). Interactivity in brand web sites: cognitive, affective, and behavioral responses explained by consumers' online flow experience. Journal of Interactive Marketing, 26(4), 223-234.

Voracek, M. (2001). Marital status as a candidate moderator variable of male-female differences in sexual jealousy: The need for representative population samples. Psychological Reports, 88(2), 553-566.

Wang, E. S. T., \& Chen, L. S. L. (2012). Forming relationship commitments to online communities: The role of social motivations. Computers in Human Behavior, 28(2), 570575.

Wang, E.S.T, Chen, L.S.L., \& Tsai, B. K. (2012). Investigating member commitment to virtual communities using an integrated perspective. Internet Research, 22(2), 199210

Wang, Y., \& Fesenmaier, D. R. (2003). Assessing motivation of contribution in online communities: An empirical investigation of an online travel community. Electronic markets, 13(1), 33-45. 
Wang, X., Yu, C., \& Wei, Y. (2012). Social media peer communication and impacts on purchase intentions: A consumer socialization framework. Journal of Interactive Marketing, 26(4), 198-208.

Wang, M., Sierra, C., \& Folger, T. (2003). Building a dynamic online learning community among adult learners. Educational Media International, 40(1-2), 49-62.

Welbourne, J. L., Blanchard, A. L., \& Wadsworth, M. B. (2013). Motivations in virtual health communities and their relationship to community, connectedness and stress. Computers in Human Behavior, 29(1), 129139.

Wu, G., (2006). Conceptualizing and measuring the perceived interactivity of websites. Journal of Current Issues \& Research in Advertising, 28(1), 87-104.

Yavas, U. (1994). Research note: students as subjects in advertising and marketing research. International Marketing Review, 11(4), 3543.
Young, C. (2013). Community management that works: how to build and sustain a thriving online health community. Journal of Medical Internet Research, 15(6), e119.

Zhao, L., Lu, Y., Wang, B., Chau, P. Y., \& Zhang, L. (2012). Cultivating the sense of belonging and motivating user participation in virtual communities: A social capital perspective. International Journal of Information Management, 32(6), 574-588.

Zheng, B., \& Warschauer, M. (2015). Participation, interaction, and academic achievement in an online discussion environment. Computers \& Education, 84, 78-89.

Zhou, Z., Zhang, Q., Su, C., \& Zhou, N. (2012). How do brand communities generate brand relationships? Intermediate mechanisms. Journal of Business Research, 65(7), 890-89 